\title{
Cash Flow Statements of Punjab National Bank and ICICI Bank: A Comparative Analysis
}

\author{
Dr Abhishek Maheshwari \\ Assistant Professor (Accounting \& Finance) \\ Asia Pacific Institute of Management, New Delhi
}

\begin{abstract}
:
The main objective of a commercial organisation is to earn profit. But there are many instances that the firm is earning huge profits but does not have cash to pay its liabilities on time and get bankrupt. So Cash flow statement has become more important because it describes about the cash profit generation capacity of the firm. In this paper the cash flow statement of two banks one from the public sector (PNB) and other from the private sector (ICICI) are analysed. Different statistical tools are used in the analysis. Performance wise ICICI is better than the PNB but on consistency grounds PNB is better than ICICI.
\end{abstract}

Key Words: Cash, Cash equivalents, Operating Activity, Investing Activity, Financing Activity.

Introduction: Cash Flow Statement (Accounting Standard - 3) is a statement that shows flow of cash and cash equivalents during the period under report. The statement shows net increase or decrease of cash and cash equivalents under each activity separately (operating/ Investing/ Financing) and collectively. It is possible for a firm to be highly profitable and not be able to pay dividends or invest in new equipments. It is possible for a firm to be highly profitable and not be able to service debt. It is also possible for a firm to be highly profitable and go bankrupt.

\section{Consider the following Questions:}

1. You are a banker evaluating a loan request from a prospective customer. What is your primary concern when making a decision regarding approval or denial or the loan request?

2. You are a wholesaler of goods and have been asked to sell your products on credit to a particular buyer. What is the major determining factor regarding approval or denial of the credit sale?

3. You are an investor in a firm and rely on the receipt of regular cash dividends as part of your return on investment. What must the firm generate in order to pay dividends?

The answer of all the above questions is cash means whether the firm is able to generate so much of cash to pay its loan installments, to pay the creditors and to pay dividends to the investors.

So cash flow statement describes about the conversion of accounting of accounting profit into the cash profit so that the firm is able to generate so much of cash to pay all its dues on time.

Types of Activities: There are 3 activities of Cash flow statement.

(1) Operating Activity

(2) Investing Activity

(3) Financing Activity 


\begin{tabular}{|c|}
$\begin{array}{c}\text { Cash and Cash } \\
\text { equivalents at the } \\
\text { beginning of the } \\
\text { year }\end{array}$ \\
-
\end{tabular}

\section{(1) Operating Activity:}

Cash flows from operating activities are primarily derived from the principal revenue-producing activities of the entity. Therefore, they generally result from the transactions and other events that enter into the determination of profit or loss. Examples of cash flows from operating activities are:

\begin{tabular}{|l|c|}
\hline \multicolumn{1}{|c|}{ Cash Inflow } & \multicolumn{1}{c|}{ Cash Outflow } \\
\hline (1) Cash Sales & (1) Cash Purchases \\
\hline $\begin{array}{l}\text { (2) } \text { Cash Received from Debtors and Bills } \\
\text { Receivables }\end{array}$ & (2) Payment to Creditors \\
\hline (3) Cash Received from Commission or Fees & (3) Payment of Operating Expenses \\
\hline (4) Royalty & (4)Payment of Wages \\
\hline (5) Refund of Income Tax & (5)Income Tax paid \\
\hline
\end{tabular}

\section{(2) Investing Activity :}

Investing activities are the acquisition and disposal of the Fixed Assets and Long term Investments.

\begin{tabular}{|l|l|}
\hline \multicolumn{1}{|c|}{ Cash Inflow } & \multicolumn{1}{c|}{ Cash Outflow } \\
\hline (1) Proceeds from sale of Fixed assets & (1)Purchase of Fixed Assets \\
\hline (2) Proceeds from sale of Investments & (2)Purchase of Investments \\
\hline (3) Interest Received & \\
\hline (4) Dividend Received & \\
\hline
\end{tabular}

(3) Financing Activity :

Financing activity are the activities which result in change in size and composition of owner's capital and borrowings of the enterprise from other sources.

\begin{tabular}{|l|l|}
\hline \multicolumn{1}{|c|}{ Cash Inflow } & \multicolumn{1}{c|}{ Cash Outflow } \\
\hline (1) Proceeds form issue of Shares for Cash & (1)Payment for Buy Back of Equity Shares \\
\hline $\begin{array}{l}\text { (2) } \text { Proceeds from issue of Debentures in } \\
\text { cash }\end{array}$ & (2)Payment of Redemption of Preference Shares \\
\hline (3) Proceeds from Long Term Borrowings & (3)Payment of Loan \\
\hline (4) Bank Loan Taken & (4)Payment of Interest \\
\hline & (5)Payment of Dividend \\
\hline
\end{tabular}

\section{Non-Cash Transactions :}

1. Conversion of debenture into equity shares

2. Conversion of Preference Shares into equity Shares

3. Issue of Bonus Shares

4. Splitting Shares of higher face value to lower face value

5. Acquisition of assets by issuing debentures

6. Acquisition of another enterprise by issue of shares

7. Depreciation or Amortization

8. Provisions

\section{REVIEW OF LITERATURE}

The study of the existing literature helps the researcher to draw the inference of the study and also helps to acquire in depth knowledge about the subject. The following are the review of some related literature: 
Franco et al (2008) develop a new metric of and study the capital market consequences of firm comparability. According to them investors, regulators, academics, and researchers all emphasize the importance of comparability. They find that analyst following is increasing in comparability, and that comparability is positively associated with forecast accuracy and negatively related to bias and dispersion in earnings forecasts Hollister et al (2008) in their study for nine countries they found that the components of accrual accounting earnings provide information incremental to that of current cash flows from operations in explaining next year's cash flows from operations. They relate the usefulness of accounting earnings components for explaining nearterm cash flows to certain country company's cash flow reports play in the investment decision making process of the shareholder?"

Marko Milojevic (2014) in their study analyze the cash flow management in the contemporary ways of conducting business in the Republic of Serbia.

Kalpesh Gelda and Dr Bhavsinh M. Dodiya (2014) conduct a comparative study on cash flow statements of Tata Chemicals Limited and Pidilite Chemicals Limited and describes about the conversion of accounting profit into the cash profits.

Dr Bhavsinh M. Dodiya and Kalpesh Gelda (2014) conduct a comparative study on the cash flow statements of state bank of india and HDFC bank and describes about the cash generating abilities of the bank.

\section{Research Methodology:}

\section{Sample Size:}

For the research purpose two banks have been selected (1) Punjab National Bank from the Public sector and (2) ICICI from the Private sector.

\section{Period of Study:}

The study is conducted for a period of five years from 2011-12 to 2015-16.

\section{Data Collection:}

In the research secondary data is used. The secondary data is collected from the following sources :

1. Published Annual reports of the selected Banks

2. Directory of Mumbai Stock exchange

3. Moneycontrol.com

4. Website of Reserve Bank of India

5. Newspapers

\section{Objectives:}

1. To ascertain the sources (receipts) of cash and cash equivalents under operating, investing and financing activities of the selected banks.

2. To ascertain applications (payments) of cash and cash equivalents under operating, investing and financing activities of the selected banks.

3. To ascertain net changes in cash and cash equivalents being the difference between sources (receipts) and applications (payments) under the three activities between the dates of two balance sheets.

4. To ascertain the trends of three activities of selected banks.

5. To ascertain the variation amongst the three activities of the selected banks.

\section{Hypothesis:}

Ho1: There is no significant difference between the trends of operating activities of the selected banks.

Ha1: There is significant difference between the trends of operating activities of the selected banks. 
Ho2: There is no significant difference between the trends of investing activities of the selected banks.

Ha2: There is significant difference between the trends of investing activities of the selected banks.

Ho3: There is no significant difference between the trends of financing activities of the selected banks.

Ha3: There is significant difference between the trends of financing activities of the selected banks.

Ho4: There is no significant difference between the means of operating activities of the selected banks.

Ha4: There is significant difference between the means of operating activities of the selected banks.

Ho5: There is no significant difference between the means of investing activities of the selected banks.

Ha5: There is significant difference between the means of investing activities of the selected banks.

Ho6: There is no significant difference between the means of financing activities of the selected banks.

Ha6: There is significant difference between the means of financing activities of the selected banks.

\section{Statistical Tools and Techniques:}

To analyse the cash flow statements of the selected banks the following tools are used :

1. Mean

2. Standard Deviation

3. Coefficient of variation

4. Paired T-Test (Significance Level @ 10\%)

Statistical Analysis

Mean, Standard Deviation and Coefficient of Variation

(Table No 1)

\begin{tabular}{|l|r|r|r|r|r|r|}
\hline \multirow{2}{*}{ Year } & \multicolumn{2}{c|}{ Operating Activities } & \multicolumn{2}{c}{ Investing Activities } & \multicolumn{2}{c|}{ Financing Activities } \\
\cline { 2 - 7 } & \multicolumn{1}{c|}{ PNB } & \multicolumn{1}{c|}{ ICICI } & \multicolumn{1}{c|}{ PNB } & \multicolumn{1}{c|}{ ICICI } & \multicolumn{1}{c|}{ PNB } & \multicolumn{1}{c|}{ ICICI } \\
\hline $\mathbf{2 0 1 1 - 1 2}$ & -811.22 & 9683.82 & -492.34 & -12280.2 & 440.38 & 3829.95 \\
\hline $\mathbf{2 0 1 2 - 1 3}$ & -1886.71 & 11102.01 & -650.85 & -9431.56 & 844.91 & 2989.72 \\
\hline $\mathbf{2 0 1 3 - 1 4}$ & 17729.1 & 4668.6 & -634.4 & -12246.5 & 988.35 & 6838.37 \\
\hline $\mathbf{2 0 1 4 - 1 5}$ & 5618.67 & -4824.49 & -848.67 & -9199.56 & 5945.72 & 15005.67 \\
\hline $\mathbf{2 0 1 5 - 1 6}$ & 17615.4 & 22428.47 & -782.74 & 3949.98 & 856.29 & -585.07 \\
\hline TOTAL & $\mathbf{3 8 2 6 5 . 2}$ & $\mathbf{4 3 0 5 8 . 4 1}$ & $\mathbf{- 3 4 0 9}$ & $\mathbf{- 3 9 2 0 7 . 8}$ & $\mathbf{9 0 7 5 . 6 5}$ & $\mathbf{2 8 0 7 8 . 6 4}$ \\
\hline Mean & 7653.05 & 8611.682 & -681.8 & -7841.56 & 1815.13 & 5615.728 \\
\hline S.D. & 9585.99 & 9928.916 & 138.865 & 6754.947 & 2318.19 & 5877.939 \\
\hline $\begin{array}{l}\text { Co- } \\
\text { Variance }\end{array}$ & 125.257 & 115.2959 & -20.3674 & -86.1429 & 127.715 & 104.6692 \\
\hline
\end{tabular}




\section{Cash flow from Operating Activities}

\section{(Chart No 1)}

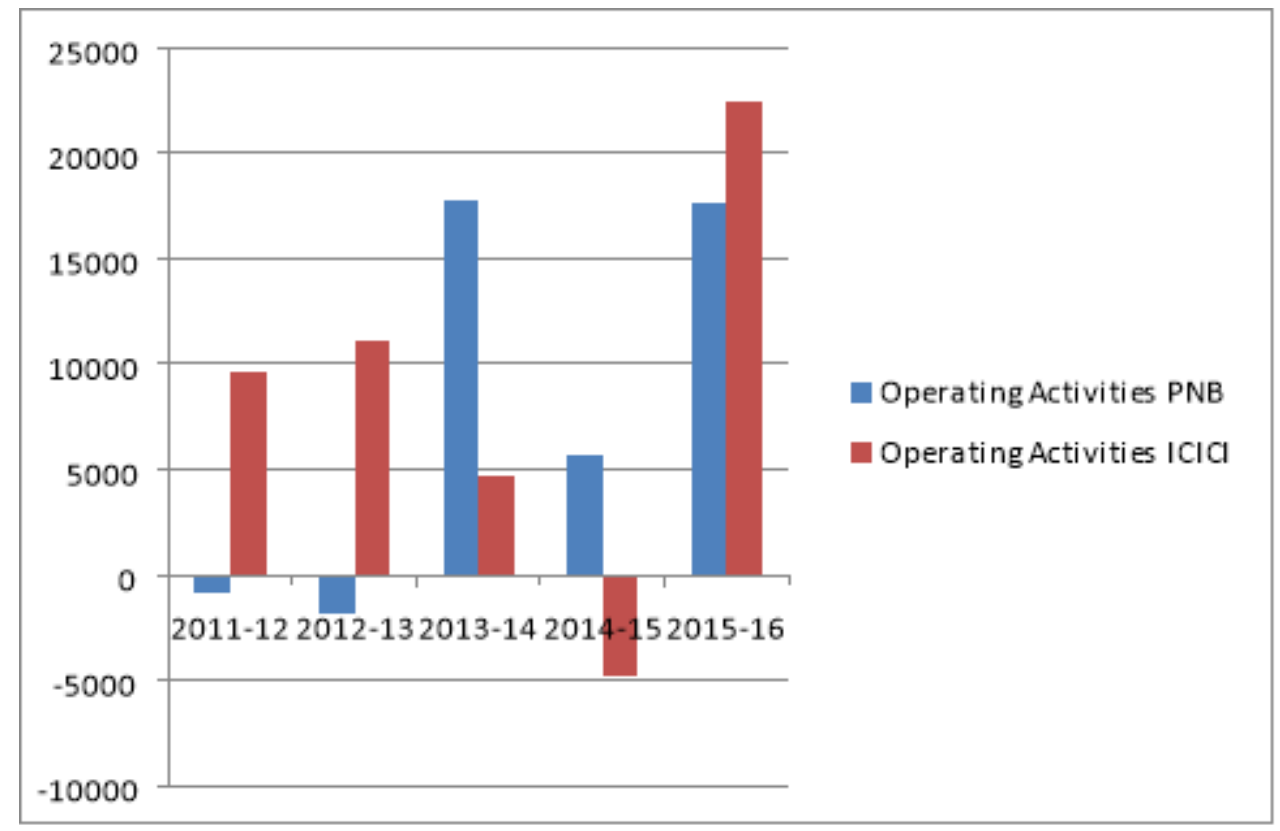

Cash flow from Investing Activities

\section{(Chart No 2)}

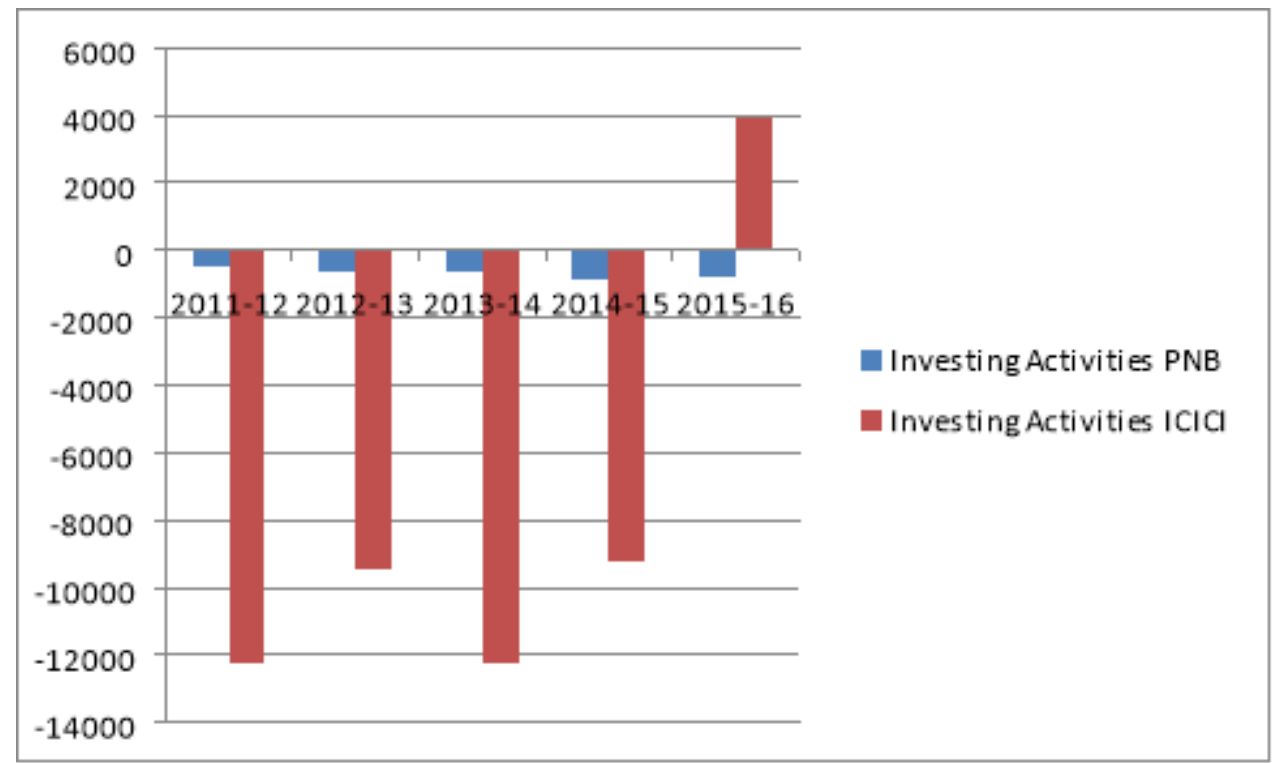




\section{Cash flow from Financing Activities}

\section{(Chart No 3)}

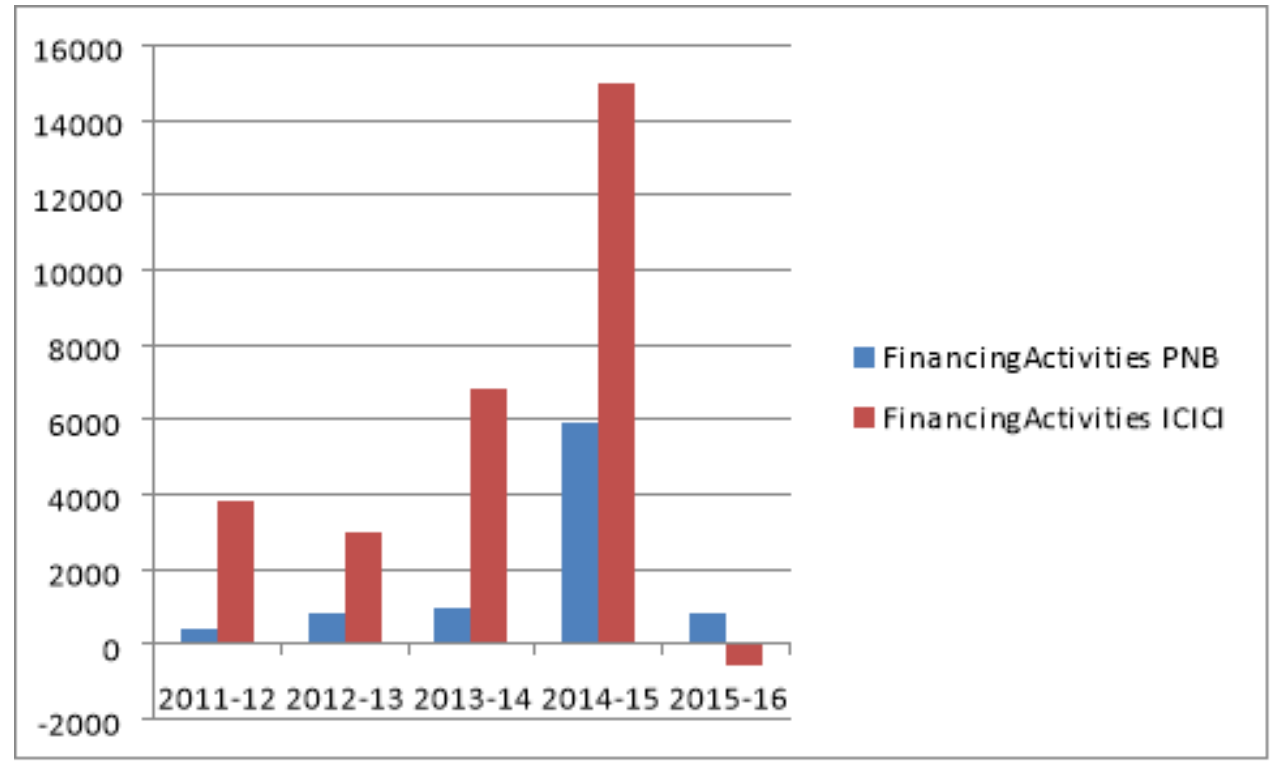

Trends Analysis of Means, Standard Deviation and Coefficient of Variation (Chart No 4)

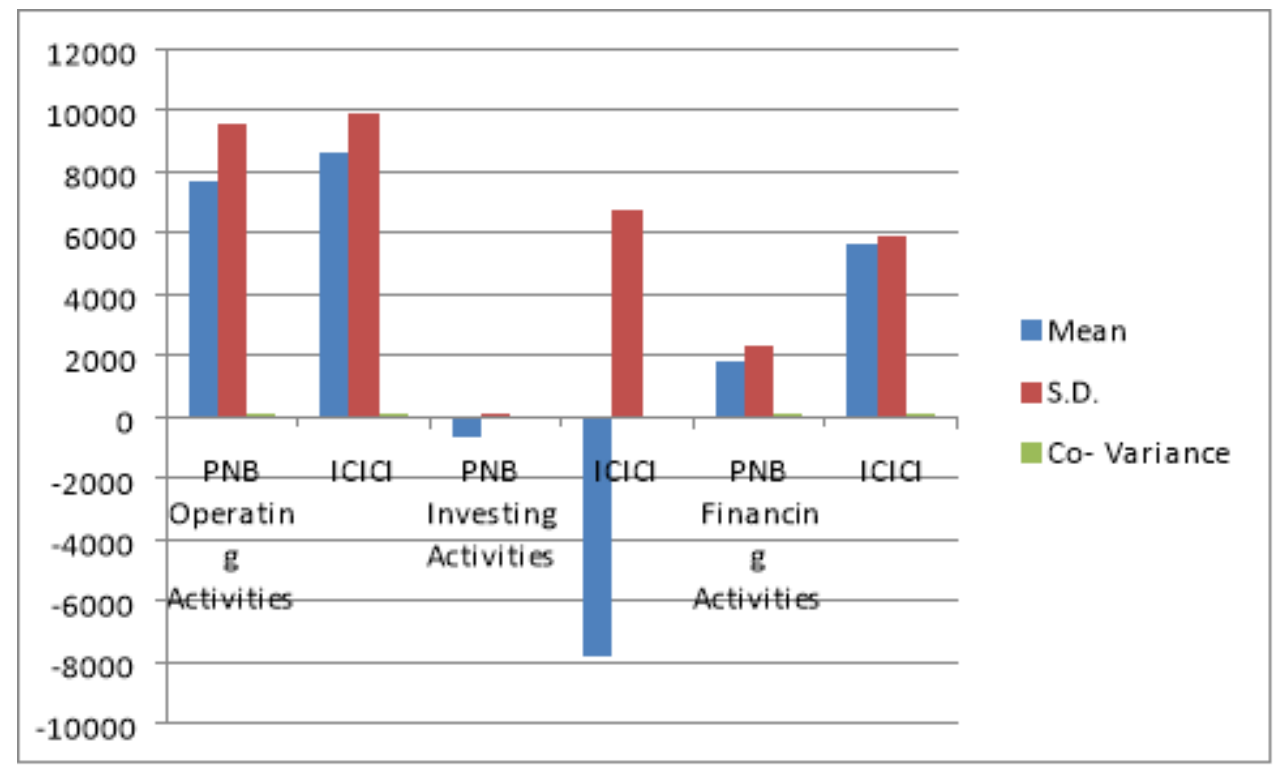




\section{PAIRED T-TEST BETWEEN TWO MEANS}

\begin{tabular}{|c|c|c|}
\hline \multicolumn{3}{|c|}{ Paired T-Test for means for Operating Activities (Table No 2) } \\
\hline & PNB & ICICI \\
\hline Mean & 7653.04 & 8611.68 \\
\hline Standard Deviation & 9585.98 & 9928.92 \\
\hline Variance & 91891012.56 & 98583452.37 \\
\hline Observations & 5.00 & 5.00 \\
\hline Mean Difference & \multicolumn{2}{|c|}{-958.64} \\
\hline D.F. & 4.00 & 4.00 \\
\hline t- Statistics & \multicolumn{2}{|c|}{-0.178} \\
\hline Sig (2 Tailed) & \multicolumn{2}{|c|}{0.867} \\
\hline \multicolumn{3}{|c|}{ Paired T-Test for means for Investing Activities (Table No 3) } \\
\hline & PNB & ICICI \\
\hline Mean & -681.80 & -7841.56 \\
\hline Standard Deviation & 138.86 & 6754.94 \\
\hline Variance & 19282.10 & 45629214.40 \\
\hline Observations & 5.00 & 5.00 \\
\hline Mean Difference & \multicolumn{2}{|c|}{7159.75} \\
\hline D.F. & 4.00 & 4.00 \\
\hline t- Statistics & \multicolumn{2}{|c|}{2.343} \\
\hline Sig (2 Tailed) & \multicolumn{2}{|c|}{0.079} \\
\hline
\end{tabular}

Paired T-Test for means for Financing Activities (Table No 4)

\begin{tabular}{|l|c|c|}
\hline & PNB & ICICI \\
\hline Mean & 1815.13 & 5615.72 \\
\hline Standard Deviation & 2318.18 & 5877.93 \\
\hline Variance & 5373958.51 & 34550061.08 \\
\hline Observations & 5.00 & 5.00 \\
\hline Mean Difference & 4.00 & -3800.59 \\
\hline D.F. & \multicolumn{2}{|c|}{-2.154} \\
\hline t- Statistics & \multicolumn{2}{|c|}{0.098} \\
\hline Sig (2 Tailed) & \multicolumn{2}{|c|}{} \\
\hline
\end{tabular}

\section{Conclusion:}

(1) From the table no 1 it is observed that the mean of operating activity of ICICI bank is higher than the PNB. Higher the mean the better for the bank. It shows that the rate of conversion of accounting profit into cash profit is higher in ICICI bank.

(2) From the table no 1 it is observed that ICICI bank is investing more in fixed assets and in investments which is a better sign. It means bank is on a growth path. Almost every year the ICICI bank is investing for the expansion of its branches. Although PNB is also investing every year in the fixed assets yet there rate of investment is lower than the ICICI bank. 
(3) From the table no 1 it is observed that to support the investing activity the ICICI bank is having more financing than the PNB. For expansion purposes ICICI bank is taking some funds from the operating activity and some from the financing activity. Although PNB is also taking funds from the financing activity yet there financing is quite lower than the ICICI bank.

(4) From the table no 1 it is observed that The standard deviation of PNB is lower than the ICICI bank in all the three activities. Lower the standard deviation, better the situation is. So it observed that PNB is having more consistency in all the three activities than the ICICI bank.

(5) From the table no 1 it is observed that The coefficient of variation of ICICI is lower than the PNB in all the three activities. Lower the coefficient of variation, better the situation is. So it observed that ICICI is having more consistency in all the three activities than the PNB.

(6) From the table no 2 it is observed that sig ( 2 tailed) value is greater than .10, so Null hypothesis is accepted which means that there is no significant difference between the means of operating activities of the PNB and ICICI.

(7) From the table no 3 it is observed that sig (2 tailed) value is less than .10, so alternate hypothesis is accepted which means that there is significant difference between the trends of investing activities of the PNB and ICICI.

(8) From the table no 4 it is observed that sig (2 tailed) value is greater than .10, so alternate hypothesis is accepted which means that there is significant difference between the trends of financing activities of PNB and ICICI.

\section{Limitations:}

(1) The study is based on secondary data only; the secondary data is having their own limitations.

(2) The entire research is based on two banks only. For getting better results some more bank should be included.

(3) The time frame is only 5 years which could be increased for getting more accurate results.

(4) As only secondary data is collected, so it is not possible to use different statistical tolls to get more analytical results.

\section{Bibliography:}

[1] I M Pandey, Financial Management, Vikas Publishing House.

[2] T.S.Grewal's Analysis of Financial Statements, Sultan Chand

[3] Van Horne- Fundaments of Financial Management, Pearson Education

[4] C.R.Kothari, Research Methodology- Methods and Techniques.

[5] S.N. Maheshwari and S.K. Maheshwari - A Textbook of Accounting for Management 2006 (1st edition), Vikas Publishing House Pvt. Ltd., New Delhi-110014.

[6] Dr. P. C. Tulsian - Financial Management, 2009, First Edition, S. Chand \& Co. Ltd., Ram Nagar, New Delhi - 110055.

[7] M. Y. Khan, P. K. Jain, Financial Management 2001, Third Edition, Tata McGraw - Hill, Publishing Company Ltd., New Delhi.

[8] N Ramchandran, Ram Kumar Kakani - How to Read a Cash Flow Statement 2010, The Mcgraw Hill Education Private Limited, West Patel Nagar, New Delhi - 110008 .

[9] Debarshi Bhattacharyya - Management Accounting, 2010, Dorling Kindersley (India) Pvt. Ltd., Panchsheel Park, New Delhi 110017.

[10] K G Gupta- Financial Management, K G Publications. 